Journal of Engineering and Applied Sciences 7 (6): 405-410, 2012

ISSN: 1816-949X

(C) Medwell Journals, 2012

\title{
Fiber Reinforced Self Compacting Concrete Using Domestic Waste Plastics as Fibres
}

\author{
${ }^{1} \mathrm{R}$. Kandasamy and ${ }^{2} \mathrm{R}$. Murugesan \\ ${ }^{1}$ Department of Civil Engineering, \\ Bhaktavatsalam Polytechnic College, Kanchipuram, Tamil Nadu, India \\ ${ }^{2}$ Anna University of Technology, Madurai, Tamil Nadu, India
}

\begin{abstract}
Fiber Reinforced Self Compacting Concrete (FRSCC) is a composite material consisting of cement based matrix with an ordered or random distribution of fiber which can be steel, nylon and polythene, etc., which offers several economical and technical benefits. In this study, domestic waste plastics (Polythene fibres) were used and the properties of concrete (viz., compressive strength, flexural strength, split tensile strength) are studied. The tests have been carried out as per EFNARC for fresh concrete and Indian Standard Code for hardened concrete.
\end{abstract}

Key words: Fibre reinforced self compacting concrete, domestic waste plastics, flowability, superplasticizer, compressive strength, flexural strength, split tensile strength

\section{INTRODUCTION}

Self-Compacting Concrete (SCC) can be defined as a fresh concrete which possesses superior flowability under maintained stability (i.e., no segregation), thus allowing self-compaction that is material consolidation without addition of energy. Self-compacting concrete was developed in Japan in 1988 as a response to the growing problems associated with concrete durability and difficulty in attracting and retaining skilled workers. SCC admixtures cannot simply be added to an existing normal concrete mix to achieve self-placing characteristics. The new mix design must be developed specifically for SCC. The addition of fibres into self-compacting concrete will take advantages of its high performance in the fresh state to achieve more uniform dispersion of fibres which is critical for a wide and reliable structural use of fibre reinforced cement composites.

In India, domestic waste plastics are causing considerable damage to the environment and hence an attempt has been made to understand whether they can be successfully used in concrete to improve some of the mechanical properties as in the case of the steel fibres. The primary objective of this investigation is to study experimentally the properties of fiber reinforced self- compacting concrete containing polythene (domestic waste plastics) fibers. The properties of concrete, namely, compressive strength and flexural strength were studied. A simple method for mix design of self-consolidating fiber reinforced concretes has been presented (Ferrara et al., 2007) and assessed through comparison with analogously designed plain self-consolidating concretes. Qucief et al. (2006) reported that the main advantage of polypropylene fiber addition is the resulting high compressive and splitting tensile strengths while the main advantage of steel fiber addition is the resulting high MOR and flexural toughness. As per the statement of Mazaheripour et al. (2011) polypropylene fibres presence in light weight concrete decreases the slump flow, no effect on compressive strength and increases the splitting tensile strength and flexural strength for maximum volume percentage of the fibres $(0.3 \%)$. Burak et al. (2009) assessed that the Polypropylene (PP) fibres elongate and slip from the matrix easily. Incorporation of fly ash resulted in a frictional bond improvement between matrix and fibre. On the other hand, Polyvinyl Alcohol Fibres (PVA) performed similar in both matrices because of its relatively rough surface structure. The flexural strength values and toughness improved significantly by incorporation of PVA fibres. However, the stability of this improvement depends on the proper adjustment of matrix and fibre properties. The concrete containing recycled plastics fiber showed promising results in compression, flexure but inconsistent results in freeze-thaw testing (Stier and Weede, 1998). Ultimate load carrying capacity of concrete, compressive strength and flexural strength is increased by using HDPP fibre and PET fibre (Venu and Rao, 2010) when compared to ordinary high performance concrete. Asad et al. (2011) concludes in his experiments that the mixture of SCC with fine rubber tire fibre recorded the best performance on flowability, passing ability, self-leveling compared to other SCC with fibres.

Corresponding Author: R. Kandasamy, Department of Civil Engineering, Bhaktavatsalam Polytechnic College, Kanchipuram, Tamil Nadu, India 
Bhogayata and Arora (2010) reported that the usage of post-consumer plastic waste in concrete as ingredient can solve its disposal problems to significant extent. Ismail and AI-Hashmi (2010) experimentally found that the use of iron and plastic waste materials is indeed, a viable solution to recycling such waste materials in concrete mixes.

Naik et al. (1996) reported that the compressive strength decreased with increase in the amount of the plastic in concrete, particularly above $0.5 \%$ plastic addition. Kandasamy and Murugesan (2011) reported that addition of domestic waste plastics in concrete for $0.5 \%$ by weight of cement gives better strength.

\section{MATERIALS AND METHODS}

The properties of the materials used in different mix of concrete were tested.

Cement: In the present investigation, ordinary portland cement 53 grade was used. The physical properties of the cement used are shown in Table 1.

Fly ash: For this investigation fly ash supplied by Ashtech (India) Pvt., Ltd. was used. The physical properties of fly ash were specific gravity 1.982 , surface area $1982 \mathrm{~m}^{2} \mathrm{~kg}^{-1}$ and colour was light grey.

Fine aggregate natural sand: In the present investigation, natural sand available from Palar river near Kanchipuram, Tamil Nadu, India conforming to zone II was used and the tests were carried out as per Indian standard in 1982. The test results are shown in Table 2 (IS: 10262, 1982).

Coarse aggregate: In the present investigation locally available blue granite crushed stone aggregates of size $20 \mathrm{~mm}$ and down was used and the various tests carried out as per Indian standard, 1963 and the test results are shown in Table 3.

Fibres: Domestic waste plastics were made into fibres and used for fibre reinforced concrete (Fig. 1).

Chemical admixtures: To achieve self-compacting concrete chemical admixtures, such as superplasticizer and viscosity modifying agents were used. With the use of superplasticizer, the water content could be reduced; thereby effective control on the water binder ratio could be maintained to achieve the design strength. Carboxylic ether polymer (viz., Glenium TMB233) was used in the present investigation. With use of viscosity modifying agents (Glenium TMS tream2) bleeding of concrete mix, segregation and sedimentation could be reduced. The properties of superplasticizer are shown in Table 4 as
Table 1: Phy sical properties of cement ( 53 grade)

\begin{tabular}{ll}
\hline Physical properties & Results \\
\hline Specific gravity & 3.15 \\
Standard consistency (\%) & $33 \%$ \\
Initial setting time (min) & $35 \mathrm{~min}$ \\
Final setting time (min) & $320 \mathrm{~min}$ \\
Compressive strength & 55.2 \\
\hline
\end{tabular}

Table 2: Properties of sand

\begin{tabular}{lc}
\hline Properties & Results \\
\hline Specific gravity of sand & 2.60 \\
Fineness modulus & 2.61 \\
Bulk density $\left(\mathrm{kg} \mathrm{m}^{-3}\right)$ & 1620 \\
\hline
\end{tabular}

Table 3: Properties of coarse aggregate

\begin{tabular}{lc}
\hline Property & Results \\
\hline Specific gravity & 2.60 \\
Bulk density $\left(\mathrm{kg} \mathrm{m}^{-3}\right)$ & 1575 \\
Fineness modulus & 7.30 \\
\hline
\end{tabular}

Table 4: Properties of superplasticizer

\begin{tabular}{ll}
\hline Technical name & Poly carboxylic ether \\
\hline Appearance & Yellowish free flowing liquid \\
$\mathrm{pH}$ & $7 \pm 1$ \\
Relative density & $1.09 \pm 0.01 \mathrm{~kg} \mathrm{~L} \mathrm{~L}^{-1}$ at $25^{\circ} \mathrm{C}$ \\
Dosage & $500-1500 \mathrm{~mL}$ per $100 \mathrm{~kg}$ of cementitious materials \\
Chloride ion content & $<0.2 \%$ \\
Alkali content & Very low \\
Operating temperature & $2-50^{\circ} \mathrm{C}$ \\
\hline
\end{tabular}

Table 5: Properties of viscosity modifying agent

\begin{tabular}{lc}
\hline Appearance & Water white viscous liquid \\
$\mathrm{pH}$ & $6.6-7.5$ \\
Volumetric mass at $20^{\circ} \mathrm{C}$ & $1.08 \mathrm{~kg} \mathrm{~L}^{-1}$ \\
Dosage & $1.00-4.00 \mathrm{~L} \mathrm{~m}^{-3}$ \\
Chloride content & $<0.1 \%$ \\
Specific gravity & 1.06 at $27^{\circ} \mathrm{C}$ \\
Operating temperature & $2-50^{\circ} \mathrm{C}$ \\
\hline
\end{tabular}

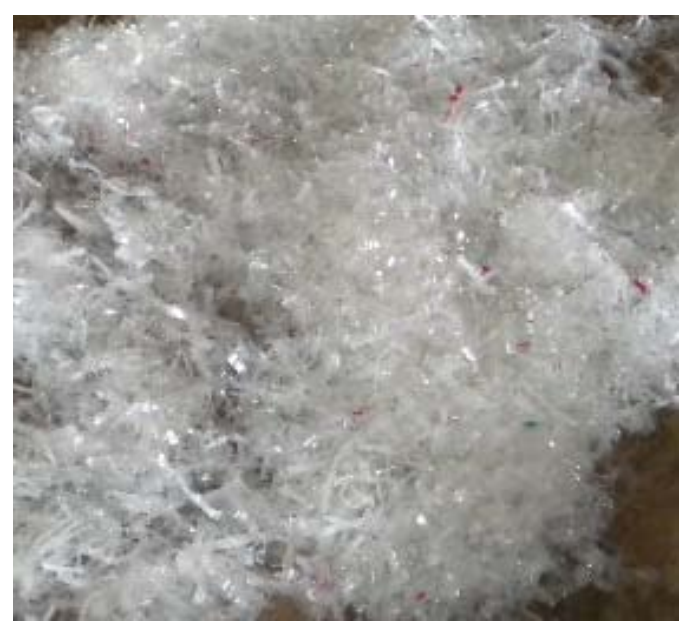

Fig. 1: Domestic waste plastics are made in to fibre

shown by the manufacturer. The properties of viscosity modifying agent as given by manufacturer is shown in Table 5 . 
Table 6: Mix proportion

\begin{tabular}{lccc} 
& & & \multicolumn{2}{c}{$\begin{array}{c}\text { Fibre Reinforced Self Compacting } \\
\text { Concrete (FRSCC) }\end{array}$} \\
Ingredients & Normal Concrete (NC) & Fibre Reinforced Concrete (FRC) & 400 \\
Cement $\left(\mathrm{kg} \mathrm{m}^{-3}\right)$ & 360 & 360 & 100 \\
Fly ash $\left(\mathrm{kg} \mathrm{m}^{-3}\right)$ & - & - & 500 \\
Powder content $\left(\mathrm{kg} \mathrm{m}^{-3}\right)$ & 360 & 360 & 821 \\
Coarse aggregate $\left(\mathrm{kg} \mathrm{m}^{-3}\right)$ & 1126.52 & 1126.52 & 741 \\
Fine aggregate $\left(\mathrm{kg} \mathrm{m}^{-3}\right)$ & 734.32 & 734.32 & 0.903 \\
FA/CA ratio & 0.652 & 0.652 & 231 \\
Water $\left(\mathrm{kg} \mathrm{m}^{-3}\right)$ & 179 & 179 & 0.462 \\
Water/Powder ratio & 0.497 & 0.497 & 1.80 \\
Domestic waste plastic fibres $\left(\mathrm{kg} \mathrm{m}^{-3}\right)$ & - & - & 2.16 \\
Superplasticizer $\left(\mathrm{L} \mathrm{m}^{-3}\right)$ & - & - & 0.36 \\
Viscous modifying agents $\left(\mathrm{L} \mathrm{m}^{-3}\right)$ & - & & \\
\hline
\end{tabular}

Table 7: Details of specimens

\begin{tabular}{llccc}
\hline Name of test & Specimen & NC (No.) & FRC (No.) & FRSCC (No.) \\
\hline Compressive strength test & Cube $150 \times 150 \times 150 \mathrm{~mm}$ & 9 & 9 & 9 \\
Flexural strength test & Prism $150 \times 150 \times 700 \mathrm{~mm}$ & 3 & 3 & 3 \\
Split tensile test & Cylinder 150 dia and $300 \mathrm{~mm}$ height & 3 & 3 & 3 \\
\hline
\end{tabular}

Water: Water is an important ingredient of concrete as it actively participates in the chemical reaction with cement. The strength of cement concrete comes from the bonding action of the hydrated cement gel. The requirement of water should be reduced to that required for chemical reaction of hydrated cement as any excess water would end up in formation of undesirable voids (and/or capillary pores) in the hardened cement paste of concrete (Neville and Brooks, 1987). In the present investigation, potable water was used.

Mix design: The Normal Concrete (NC) mix was designed as IS: 10262 (1982) for M30 grade. For the same mix, domestic waste plastic fibres of $0.5 \%$ by weight of cement is added for fibre reinforced cement concrete FRC. Nan et al. (2001) gave a simple procedure for selfcompacting concrete mix design based on the packing factor. In this study, the Japanese method of self- compacting concrete mix design (Kumar, 2006) was followed and domestic waste plastic fibres of $0.5 \%$ by weight of cement FRSCC are added. Table 6 shows the different mix proportions adopted in the present study.

Preparation of test specimens: The concrete cubes, cylinders and beams were cast using standard steel moulds. Concrete was mixed in a tilting type mixer machine. Concrete was placed uniformly in three layers and each layer was compacted by ramming rod. Excess concrete was removed and top was finished by trowel. The sides of the mould were removed $24 \mathrm{~h}$ after casting and the test specimens were cured in water. Cubes of size $150 \times 150 \times 150 \mathrm{~mm}$ were cast to evaluate the compressive strength of concrete, cylinders of size $150 \mathrm{~mm}$ dia and $300 \mathrm{~mm}$ height were cast for split tensile strength and beams of size $150 \times 150 \times 700 \mathrm{~mm}$ were cast (Fig. 2) to evaluate the flexural strength. The specimens were taken
Table 8: Test result of fresh concrete

\begin{tabular}{llrrr}
\hline & & \multicolumn{3}{c}{ Typical range of values } \\
Methods & Unit & Minimum & Maximum & Mix-1 \\
\hline Slump-flow by Abram's cone & $\mathrm{mm}$ & 650.0 & 750 & 680.00 \\
$\mathrm{~T}_{500 \text { mm }}$ slump flow & $\mathrm{S}$ & 2.0 & 5 & 3.50 \\
J-Ring & $\mathrm{mm}$ & 0.0 & 10 & 9.00 \\
V-funnel & $\mathrm{S}$ & 8.0 & 12 & 10.50 \\
V-funnel@ $\mathrm{T}_{5 \text { min }}$ & $\mathrm{S}$ & 0.0 & +3 & 2.50 \\
L-box & $(\mathrm{H} 2 / \mathrm{H} 1)$ & 0.8 & 1 & 0.92 \\
U-box & $(\mathrm{H} 2 / \mathrm{H} 1)$ & 0.0 & 30 & 12.00 \\
\hline
\end{tabular}

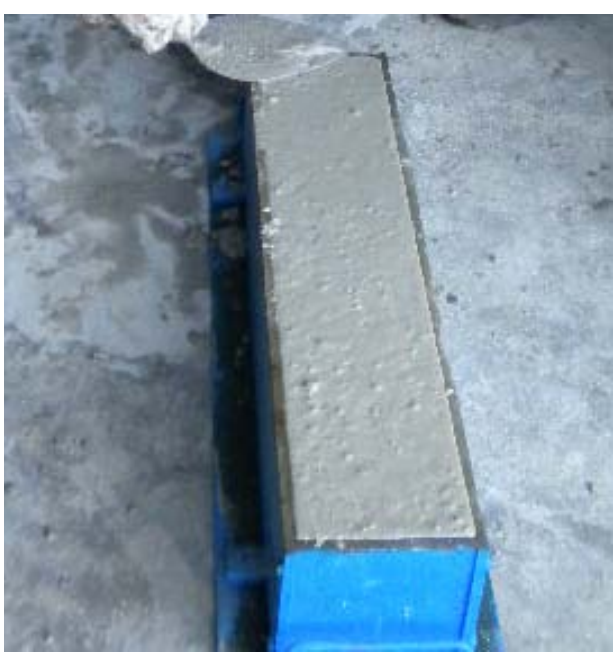

Fig. 2: Casting of beams

out from water after 3,7 and 28 days for testing. Table 7 shows the details of specimens used in the study.

Fresh concrete: Experiments on fresh and hardened concrete were conducted. In fresh SCC concrete, the properties such as filling and passing ability of concrete were investigated. The test setup for the fresh concrete was done as per the SCC EFNARC guidelines. Aggarwal et al. (2004) results are shown in Table 8. 


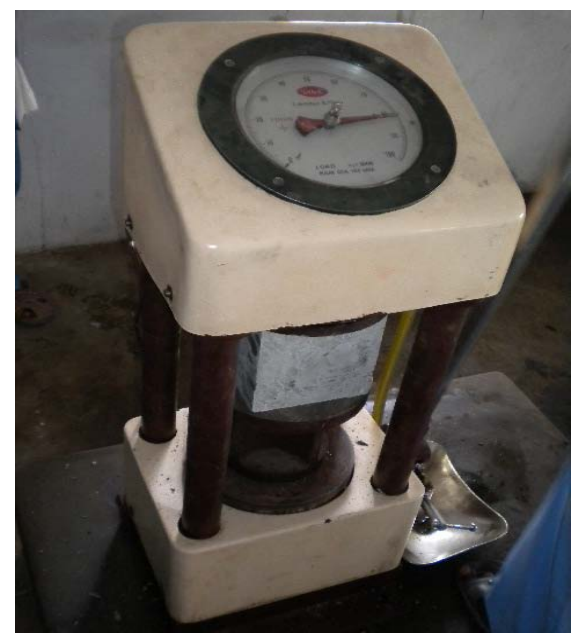

Fig. 3: Testing of beam cubes

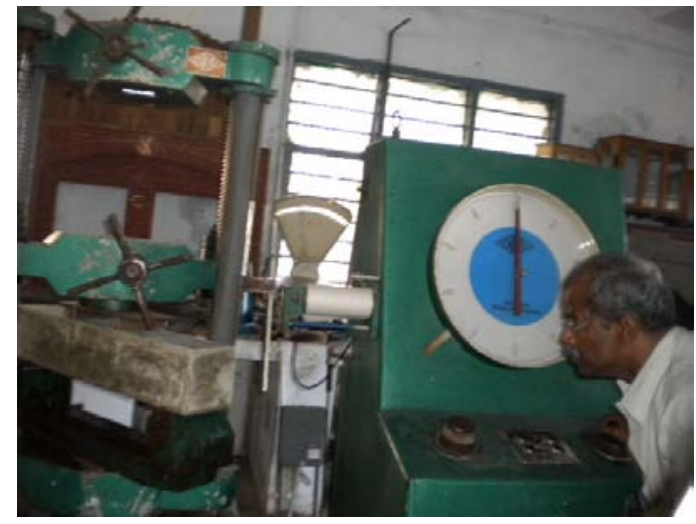

Fig. 4: Testing of beam specimens

\section{Hardened concrete}

Compressive strength test: Nine cubes in each grade of concrete were prepared and tested as IS: $516(1959)$ at 3,7 and 28 days. The cube specimen was placed in the machine in such a manner that the load is applied to opposite sides of the cubes as cast that is not to the top and bottom. The axis of the specimen was carefully aligned with the centre of thrust of the spherically seated platen. The load was applied without shock and increased continuously at a rate of approximately $14 \mathrm{~N} / \mathrm{mm}^{2} / \mathrm{min}$ until the resistance of the specimen to the increasing load breaks down and no greater load sustained. The maximum load applied to the specimen was recorded (Fig. 3).

Flexural strength test: Three prisms of size $150 \times 150 \times$ $700 \mathrm{~mm}$ were prepared in each type of concrete and tested after 28 days curing. The test was carried out in the Universal testing machine as IS: 5816 (1999). The bearing surfaces of the supporting and loading rollers was wiped clean and the specimen was placed in the machine in such

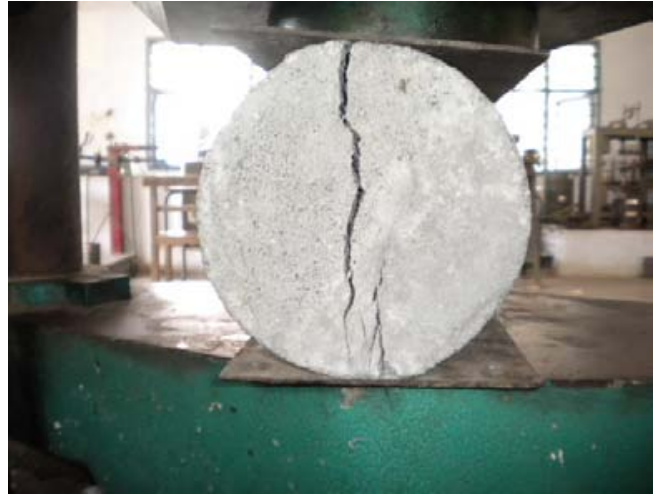

Fig. 5: Split tensile strength testing

a manner that the load applied to the uppermost surface as cast in the mould, along two lines spaced $20 \mathrm{~cm}$ apart. The axis of the specimen was carefully aligned with the axis of the loading device. The load was applied without shock and increasing continuously at a rate such that the extreme fibre stress increases at approximately $0.7 \mathrm{~N} / \mathrm{mm}^{2}$ / $\mathrm{min}$ that is at a rate of loading of $4000 \mathrm{~N} \mathrm{~min}^{-1}$. The load was increased until the specimen fails and the maximum load applied to the specimen during the test was recorded (Fig. 4).

Splitting tensile test: Three cylinders of size $150 \mathrm{~mm}$ diameter and $300 \mathrm{~mm}$ height were prepared in each grade of concrete and tested as IS:383 (1970) at 28 days. The bearing surface of the testing machine and of the loading strips was wiped clean.

The test specimen was placed in the centring jig with packing strip and loading pieces carefully positioning along the top and bottom of the plane of loading of the specimen. The jig was placed in the machine so that the specimen is located centrally. The load was applied without shock and increased continuously at a nominal rate within the range $1.2-2.4 \mathrm{~N} / \mathrm{mm}^{2} / \mathrm{min}$. Maintain the rate, once adjusted, until failure. The maximum load applied was recorded (Fig. 5).

\section{RESULTS AND DISCUSSION}

Effects on compressive strength: The cube compressive strength for different types of concrete was obtained. Comparison of compressive strength of different types of concrete after 3 days curing is shown in Fig. 6. It can be shown that after 3 days curing, average compressive strength of fibre reinforced concrete $\mathrm{FRC}$ is $5.23 \%$ higher than Normal Concrete (NC) and compressive strength of Fibre Reinforced Self-Compacting Concrete (FRSCC) is improved further by $3.26 \%$. 


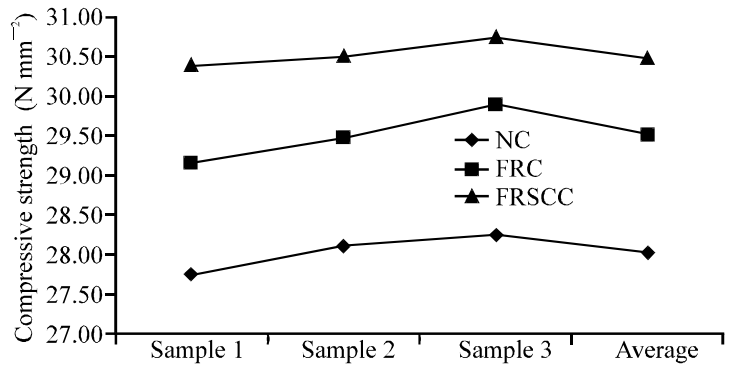

Fig. 6: Comparison of compressive after 3 days

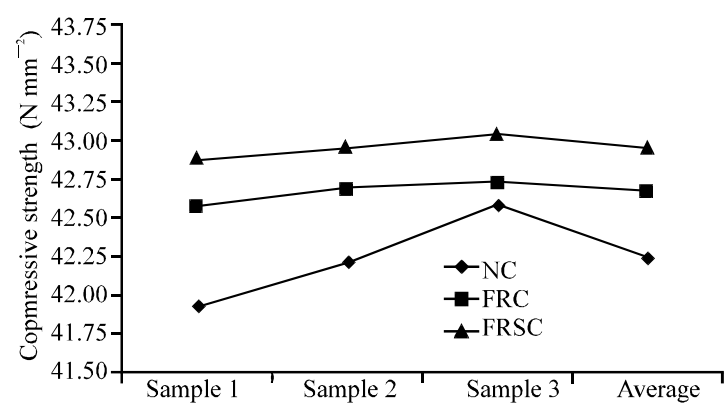

Fig. 7: Comparison of compressive strength after 7 days

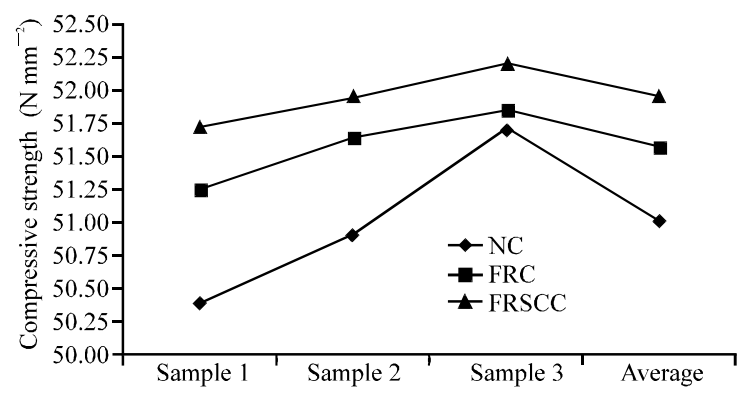

Fig. 8: Comparison of compressive strength after 28 days

Figure 7 shows the compression of compressive strength after 7 days curing different types of concrete. It can be shown that after 7 days curing, average compressive strength of fibre reinforced concrete FRC is $1.19 \%$ higher than Normal Concrete (NC) and compressive strength of Fibre Reinforced Self-Compacting Concrete (FRSCC) is improved further by $0.81 \%$.

Figure 8 shows the comparison of compressive strength of different types of concretes after 28 days curing. It shows the average compressive strength of fibre reinforced concrete FRC is $0.90 \%$ higher than Normal Concrete (NC) and compressive strength of Fibre Reinforced Self-Compacting Concrete (FRSCC) is improved further by $0.64 \%$.

In all the earlier cases, compressive strength of concrete with manufactured sand is slightly higher than that of concrete with sand. Further, the compressive

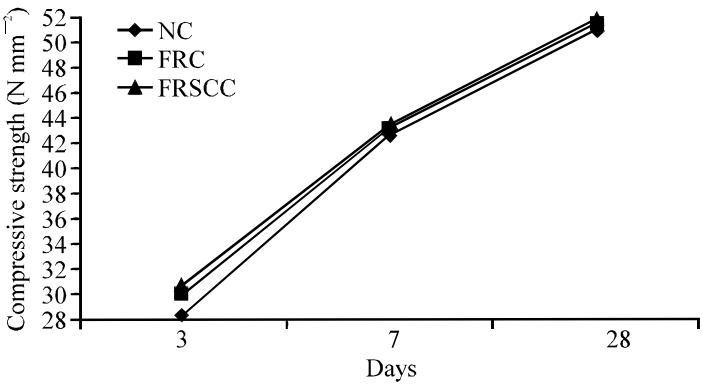

Fig. 9: Comparison of compressive strength after 3,7 and 28 days

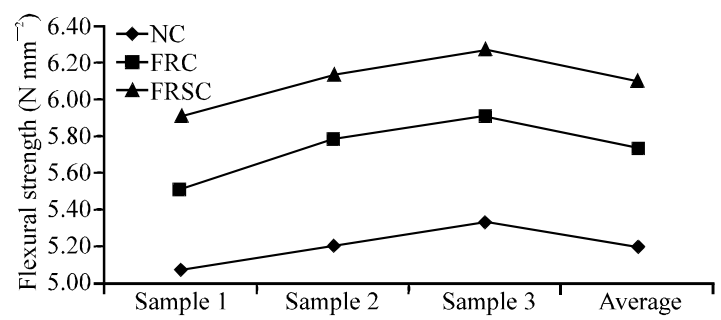

Fig. 10: Comparison of flexural strength

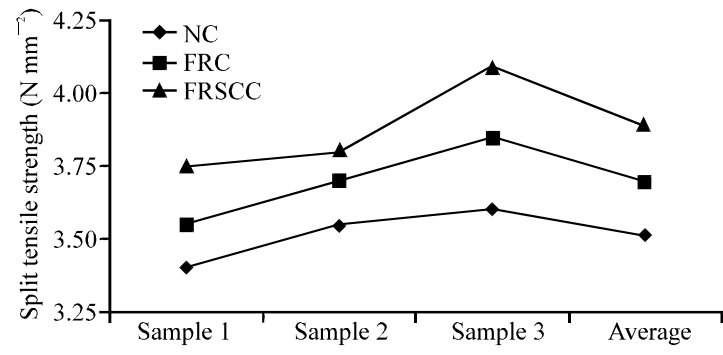

Fig. 11: Comparison of split tensile strength

strength of fibre reinforced concrete with manufactured sand is little more than that of the concrete with manufactured sand. The reason for this is that the compressive strength depends to a large extent depends on quality of cement, shape and size of aggregate which are same for concrete using sand or manufactured sand. Average compressive strength of different mix at 3,7 and 28 days are shown (Fig. 9).

Effects on flexural strength: The prism flexural strength tests of different type of concrete were obtained. The comparison of flexural strength of different types of concrete after 28 days curing is shown in Fig. 10. It is seen that the average flexural strength of Fibre Reinforced Concrete (FRC) is 10.26 higher than Normal Concrete (NC) and flexural strength of Fibre Reinforced Self-Compacting Concrete (FRSCC) is improved further by $6.46 \%$. The reason for this variation is due to the bond strength of the fibre. 


\section{J. Eng. Applied Sci., 7 (6): 405-410, 2012}

Effects on split tension test: The cylinder split tensile strength tests of different grade of concrete are obtained and Fig. 11 shows the comparison of tensile strength of different types of concrete after 28 days. It is shown that the average splitting tensile strength of Fibre Reinforced Concrete (FRC) is $5.37 \%$ higher than Normal Concrete (NC) and tensile strength of Fibre Reinforced SelfCompacting Concrete (FRSCC) is improved further by $5.10 \%$. This may be due to the bond strength of the fibre.

\section{CONCLUSION}

Based on the experimental investigation carried out on the three types of concrete namely, ordinary concrete with river sand, concrete with manufactured sand and fibre reinforced concrete with manufactured sand, the following results are drawn. Addition of $0.5 \%$ of polythene (domestic waste polythene bags) fiber to concrete:

- There is no much difference in the compressive strength of Fibre Reinforced Self-Compacting Concrete (FRSCC) and that of fibre reinforced concrete FRC or Normal Concrete (NC)

- Flexural strength (Modulus of rupture) of fibre Reinforced Self-Compacting Concrete (FRSCC) is more than that of Fibre Reinforced Concrete (FRC) or Normal Concrete $(\mathrm{NC})$. The difference is quite appreciable

- Tensile strength (Split tensile strength) of Fibre Reinforced Self-Compacting Concrete (FRSCC) and that of Fibre Reinforced Concrete (FRC) or Normal Concrete (NC)

- Pollution control is achieved by disposal of domestic waste plastics as fibres while using for fibre reinforced concrete

\section{REFERENCES}

Aggarwal, P., R. Siddique, Y. Aggarwal and S.M. Gupta, 2004. Mixture proportioning procedures for selfcompacting concrete. http://lejpt.academicdirect.org/ A12/015_024.htm.

Asad, S., P. Gunawan and M.S. Alaydrus, 2011. Fresh state behavior of self compacting concrete containing waste material fibres. Procedia Eng., 14: 797-804.

Bhogayata, A. and N.K. Arora, 2010. Use of postconsumer plastic wastes in concrete. Structural Engineering Digest, http://sedigest.in/article/usepost-consumer-plastic-wastes-concrete.
Burak, F., K. Tosun and B. Baradan, 2009. Effects of fibre type and matrix structure on the mechanical performance of self-compacting micro-concrete composites. Cem. Concr. Res., 39: 1023-1032.

Ferrara, L., P. Yon-Dong and S.P. Shah, 2007. A method for mix-design of fibre-reinforced self-compacting concrete. Cement Concr. Res., 37: 957-971.

IS: 10262, 1982. Recommended guidelines for concrete mix design. Code of Practice, Bureau of Indian Standards, New Delhi, India.

IS: 516,1959 . Methods of tests for strength of concrete. Code of Practice, Bureau of Indian Standards, New Delhi, India.

IS: 5816,1999 . Splitting tensile strength of concretemethod of test. Code of Practice, Bureau of Indian Standards, New Delhi, India.

IS:383, 1970. Indian standard specification for coarse and fine aggregates from natural sources for concrete. Code of Practice, Bureau of Indian Standards, New Delhi, India.

Ismail, Z.Z. andE.A. AI-Hashmi, 2010. Validation of using mixed iron and plastic wastes in concrete. Proceedings of the 2nd International Conference on Sustainable Construction Materials and Technologies, June 28-30, 2010, The University of Wisconsin Milwaukee Centre for By-products Utiliztion, Itlay, pp: 1-11.

Kandasamy, R. and R. Murugesan, 2011. Fibre reinforced concrete using domestic waste plastics as fibres. ARPN J. Eng. Applied Sci., 6: 75-82.

Kumar, P., 2006. Self-compacting Concrete: Methods of testing and design. J. Inst. Eng., 86: 145-150.

Mazaheripour, H., S. Ghanbarpour, S.H. Mirmoradi and I. Hosseinpour, 2011. The effect of polypropylene fibers on the properties of fresh and hardened lightweight self-compacting concrete. Constr. Build. Mater., 25: 351-358.

Naik, T.R., S.S. Singh, C.O. Huber and B.S. Brodersen, 1996. Use of Post-consumer waste plastics in cementbased composites. Cem. Concr. Res., 26: 1489-1492.

Nan, S., H. Kung-Chung and C. His-Wen, 2001. A simple mix design method for self-compacting concrete. Cem. Concr. Res., 31: 1799-1807.

Neville, A.M. and J.J. Brooks, 1987. Concrete Technology. Longman Scientific and Technical, New York, USA.

Qucief, H., J. Zeghiche and M.F. Habita, 2006. Hybrid fibre reinforced self-compacting concrete: Fiber synergy at low fiber volume fraction. J. Eng. Applied Sci., 1: $112-116$.

Stier, K.W. and G.D. Weede, 1998. A study conducted to investigate the feasibility of recycling commingled plastics fiber in concrete. J. Ind. Technol., 15: 1-8.

Venu, M. and P.N. Rao, 2010. Effect of non bio degradable waste in Concrete slabs. Int. J. Civil Struct. Eng., 1: $449-457$. 